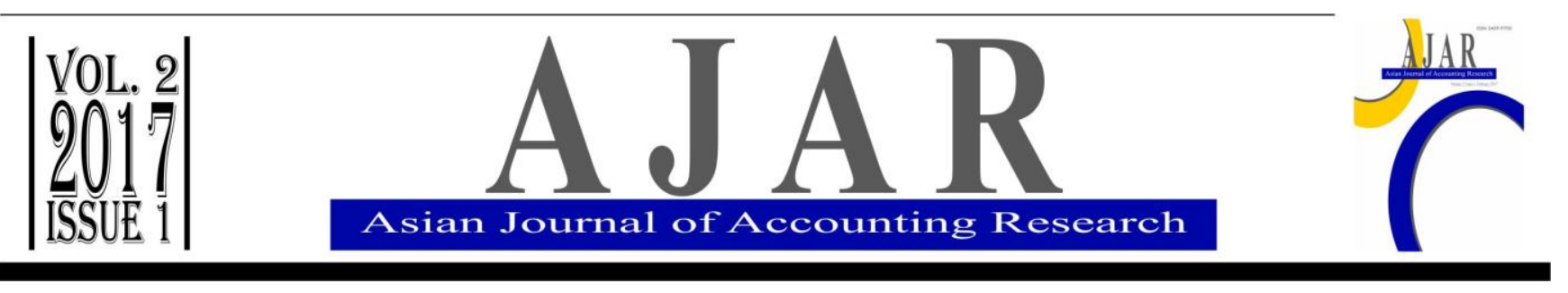

\title{
Concept of Remuneration and Management Behavior Evaluation in Indonesia
}

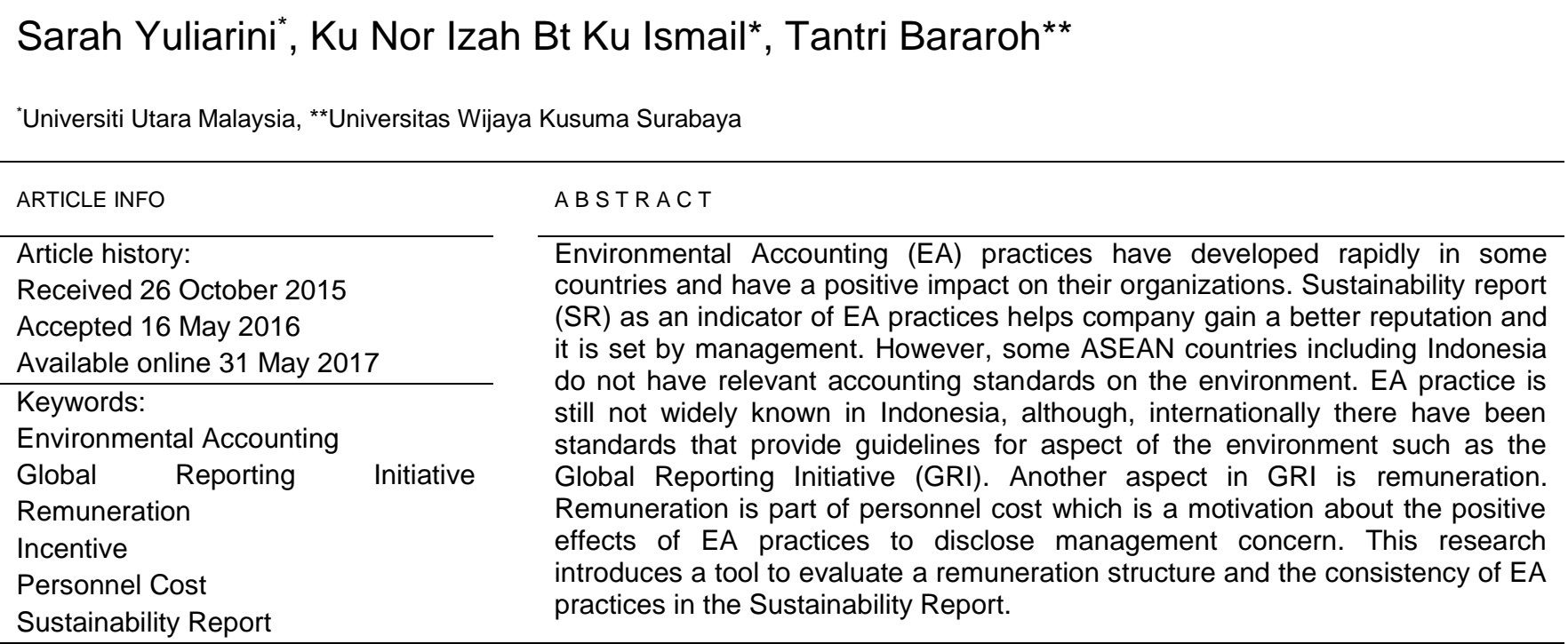

\section{Introduction}

The word of 'environment' is an important dimension in our life (Yusoff and Lehman, 2009). The simple definition of environment is a 'surrounding' (Guo, Ai and Polenske, 2008). Environment is the combination of all physical and organic factors that act on a living being, or an ecological society and power (Yusoff and Lehman, 2009), its endurance and growth are used to support economic system and human welfare (Barbier, 1989, 3). Other researchers named it as 'biodiversity related' (Jones, 2003; Cho, 2007). They believe that the environment should be taken into account and treated as part of business strategy.

Cagatay and Mihci (2006) argue that limitation of economic growth is caused by environmental degradation. The environment provides all primary inputs for economic activities especially in manufacturing, but it has limited availability. Environmental accounting and accountancy profession should have a solid role to help both public and private firms improve the use of resources efficiently, accelerate productivity as well to enhance profitability (TBL framework). Previous studies have investigated the importance of environmental accounting and focused on the impact of economics by enhancing brand equity (Benoit-moreau and Parguel, 2011), social issues by avoiding community ban on business operation (Beck, Campbell and Shrives, 2010) and environment by minimizing the negative impact on natural resources (Farouk, Cherian, and Jacob, 2012). Moreover, EA can be used as a marketing tool for communicating with external parties about environmental activities done by the company (Pickett-Baker and Ozaki, 2008).

Disclosure of environmental accounting information is a key process in performing accountability (Bewley, 2005; Brown and Fraser, 2006; Firoz and Ansari, 2010). It also helps company build a satisfactory environment image and create competitive advantage. Environmental accounting is not only an accounting term, but it is also coined to 'sustainable development'. Sustainable development becomes an essential condition for a company to participate in market competition and realize its self-esteem.

However, the implementation of EA in some countries which do not have an accounting standard on environmental accounting could be difficult to keep the sustainability practices. The policy depends on internal management. To impose an external demand or externality, management requires a reward as motivation for implementing related policies. When we discuss about management interests, we are back to the traditional cost and benefit clause. This practice is more transactional than transformational when there is no specific standard for supporting the practice.

This issue is closely related to two elements: (1) the benefits of environmental accounting in relation to the practices of management which EA should recognize, and measure, (2) the impact of beneficiary management through the evaluation interrelationship between remuneration and sustainability report. 


\section{Measuring Beneficial of EA}

As stated by 'Agenda 21' of the Rio Summit on Environment and Development organized by the United Nations in 1992, "Natural disasters cause loss of life, disruption of economic activities and urban productivity, particularly for highly susceptible low-income groups, and environmental damage, such as loss of fertile agricultural land and contamination of water resources, and can lead to major resettlement of populations ( $p$. $57)$.

Measuring benefits needs to consider on the merits for the external stakeholders and internal management intentions. The benefits of EA practices for the external beneficiaries are considered under financial accounting disclosed in the financial statements, while the internal beneficiaries are managed by management accounting. However in any case, standardisation practices are less relevant for environmental management accounting than it is for external reporting (Association of Chartered Certified Accountants, 2004, 65)

Environmental accounting (EA) could be an important marketing tool because it communicates with external parties about a company's environmental activities (Benoit-moreau and Parguel, 2011). It also helps a company to establish a satisfactory environment image and create competitive advantage (Beck et al., 2010; Raska and Shaw, 2012). Environmental accounting is not only a matter for accounting, but also for sustainable development (Husser et al., 2012; Farouk et al., 2012). The sustainable development has become an essential condition for enterprises to take part in a competitive market and realize its self-value.

Accounting can affect the behavior of individuals or organizations extensively to be more transparent, objective and efficient. This behavior changing does not happen automatically. The implementation of environmental accounting is an external policy imposed by law and other stakeholders such as consumers, NGOs and international or pleaded as interventionist regulation (Yakhou and Dorweiler, 2004).

A new policy means extra work. In this case, remuneration and incentives can motivate belowmanagement level to support any policy of top management. Legitimacy is in the hands of the CEO (for the case in Indonesia), but if it is not given as a wholehearted support of all layers to the structure of an organization, the environment and social policy might become skepticism (Raska and Shaw, 2012). At the time the company has been practicing EA, it can meet some problem which is a series of recognition and systematic recording of environmental activities undertaken by management.

\section{Legitimacy structure on remuneration measurement}

Generally, accounting conservatism term in environmental accounting practices is associated with the determination of the allocation of environmental costs into conventional accounting overview. The main principle of accounting conservatism is to see the effect of losses in the current period, as the first order shall be made before recognizing any profit as a legal claim. It is linked to a business motive which is taken as a primary consideration in any decision-making and business strategy. Therefore, every regulation should fit to business interests (Yakhou and Dorweiler, 2004).

The regulation should also be adjusted to the internal purposes and it depends on the strength of legitimacy within the organization. As revealed by Darmadi (2012) using Tobin's Q method, principal-agent conflicts appear to be more prevalent in corporations with diffused ownership structure, where there is no a single majority shareholder in firms concentrated on ownership. Such problems may exist between controlling shareholder and minority shareholders. Here, remuneration structure seems to depend on ownership structure.

According to the Sustainability Reporting Generation 4 (GRI-SRG4) section LA13 on Manual Sustainability Reporting Guidelines, the benefits for management about remuneration or incentive are divided in several criteria. The measurement is based on payroll and capital structures:

i. The highest level of governance body and the board of directors to the level below, on the basis of measurements of fixed periodic payments, variable periodic payments, incentive or bonuses, latest payments, and the recovery of money already disbursing, termination payments.

ii. The highest level of governance body. Remuneration becomes a part of capital equity which is representing of wealth of shareholders.

Ideally, the appreciation for supporting company's strategy to environmental conservation is given by the highest governance body to employee. The aim is to get their loyalty, to maintain the quality of work, and increase productivity (Li-Chin and Taylor, 2007). In accounting principles, employee appreciation and performance must be measured in quantity, so that the information can be given in a transparent manner.

In fact, transparency of remuneration as part of EA reporting in Indonesia is provided to the highest level of governance or executives (Darmadi, 2012). He examined the determinants of compensation structure of the Indonesian listed corporations and found firm performance, board structure, ownership structure, and firmspecific characteristics are significantly associated with remuneration structure.

The reason for giving remuneration to the board executive members or executives is to avoid the agency problems. The main role of board executive members is to observe and control agency cost as in earnings management activities. It becomes benchmark for below management level for performing activities in accordance to their higher level (Bassett, Koh, and Tutticci, 2007). 


\section{Allocating benefits to the proper parties}

Some arguments have been given as an emphasis on the benefits of EA practices for management. Amongst the topic of EA, there are better practices about its beneficiary to the organization for all structure from top to bottom line rather than from bottom to top line (Global Reporting Initiative, 2011).

Top-down approach gives a discourse image to external stakeholders about the performance of executive board members supporting the needs of shareholder and powerful publicity for every action to other stakeholder attention. The benefit given to shareholders is a definitely capital revenue (Global Reporting Initiative, 2011). It shows the success of a business strategy run by the CEO, while the bottom-up approach shall be determined through disclosure of human resources (Eugénio, 2009).

Explicitly, GRI inscribes about reporting the benefits for employees and for the executive board members. Some disclosure items as listed as follows:

I. Reporting the process for determining remuneration, whether remuneration consultants are involved in determining remuneration and whether they are independent from management or not. Reporting other components which the remuneration consultants have related to the organization.

II. Reporting how stakeholders' views are sought and taken into account regarding remuneration, including the results of votes on remuneration policies and proposals, if applicable.

III. Reporting the ratio of the annual total compensation for the organization's highest-paid individual in each country of significant operations to the median annual total compensation for all employees (excluding the highest-paid individual) in the same country.

IV. Reporting the ratio of percentage which increases in annual total compensation for the organization's highest-paid individual in each country of significant operations to the median percentage increase in annual total compensation for all employees (excluding the highest-paid individual) in the same country.

Figure 1. Evaluation on Remuneration

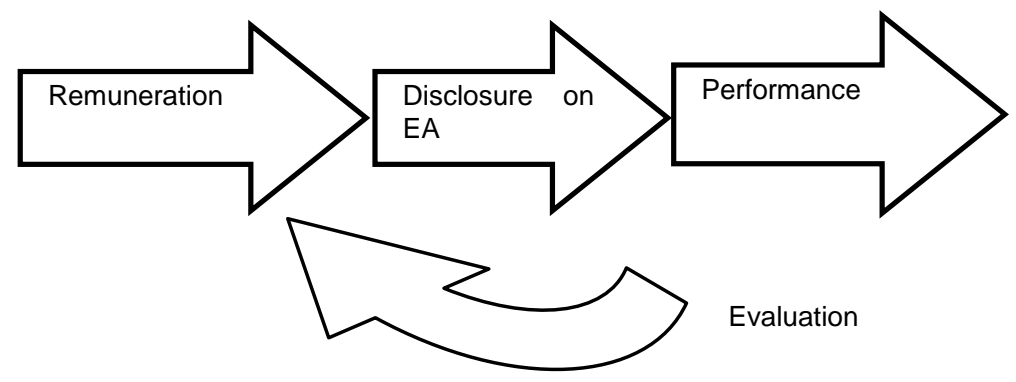

Source: Authors

Based on Global Reporting Initiative (2011), it sums up that the distinguished method of remuneration given to the employees and the highest management level based on the amount of wages received by the principle that there shall be a clear benefit which is not caused by the aggregate income widened in the same level. Figure 1 shows the relationships amongst remuneration, disclosure on environmental accounting practices and performance expected which need to be evaluated at the end of the accounting period to avoid unsignificant performance on remuneration allocation.

\section{Impact of Remuneration on Management Behavior}

Remuneration structure under the guideline of GRI is more determined than without any standard assistance. Studies about decision making on specific accounting policy is based on Trotman, Tan and Ang (2011) who suggests that research on the judgment and decision making in accounting can be inferred from management motivation in which the impact of personality factors on motivation also should be investigated. Hunton and Rose (2008) report that audit committee lack of monitoring on revenue recognition under SEC requirement because of busy directors. However, they do not explain the reason or motivation of busy directors such as due to private issues or another project giving higher incentives or remuneration matter.

Dealing with incentives, Libby and Lipe (1992) investigated the interaction of cognition process, performance and incentives using U-test. They argue that performance-based monetary incentives will have an impact on experimental results which depends on: (1) the number and types of cognitive processes required for the task (i.e., the task structure), (2) the degree of relevant determinant has taken place prior to the experiment (i.e., expertise), and (3) the existing level of intrinsic incentives. Libby and Lipe (1992) put level of intrinsic incentives as determinant variables for accounting performance, but they do not put the recognition on statutory legitimacy in the specific task. Considering compliance to regulatory legitimacy on the environmental issues should be part of business continuity. It is a specific task for management but not for organisation. Thus, the 
intrinsic incentives related should depend on performance that has regulatory imposed on the effort. Legitimacy theorists believe that business entities provide environmental information to show that they have been good stewards of the earth (Freedman and Stagliano, 2004). According to Tilling (2008) business entities motivate people to do this as a means of legitimization.

\section{Evaluating remuneration structure}

It is important to develop an identification of determinant of remuneration in order to motivate management in supporting EA practices continuously as Yang, Dolar and Mo (2014) found that there is a significant association between executive compensation and firm performance mere on cash-based than on stock-based. We suggest the concept of equation of $y=f(x)$ to explain the inter-correlation between variable $(y)$ as expected output for management (remuneration level) and variable that become determinant inputs that imply on (x) number of disclose of GRI items especially on environmental aspect. This is which Libby and Lipe (1992) called as task structure, and firm performance by Darmadi (2012) and using variables of accounting conservatism, compliance to regulatory, year, company size, industrial classification to get the least absolute deviation of regressions (Coles, Daniel and Naveen, 2008)

The concept of the remuneration impact evaluation can be followed as shown in Figure 2. In that figure, it can be seen the effect on variation remuneration expenditure that will be addressed by the top management affecting heuristic manner which the company takes as an expenditure.

Figure 2. Behavioral remuneration level and reporting level

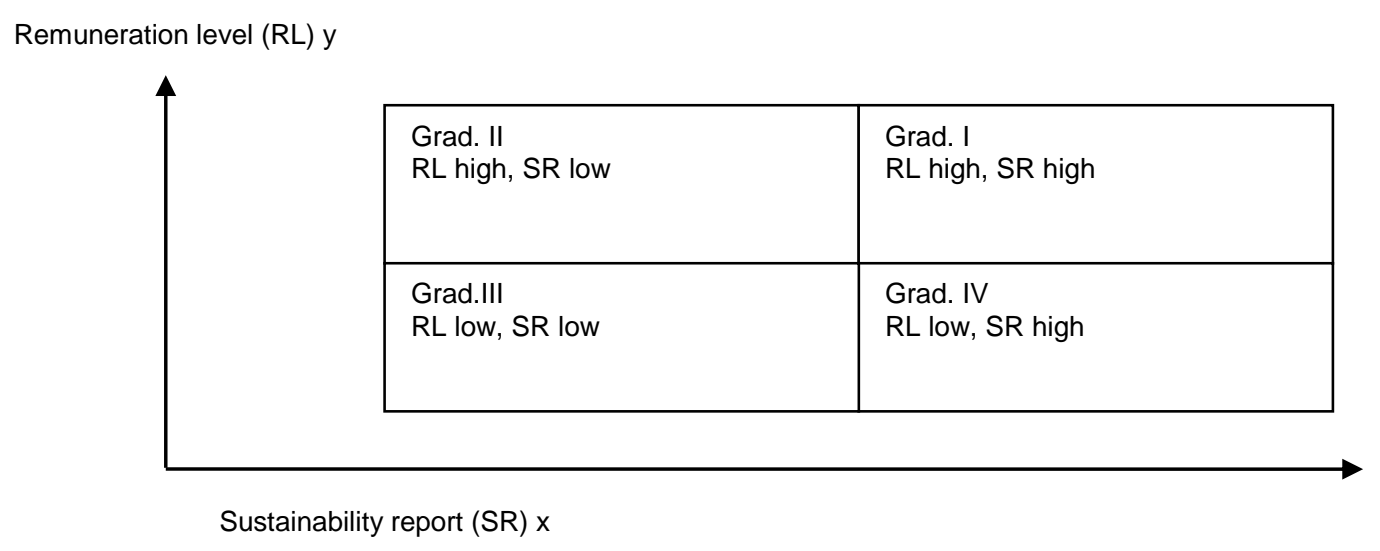

Source: Author

The first gradient shows high Remuneration Level $(R L)$ with high sustainability report level $(S R)$. It is assumed that employees will be motivated to exert effort if they believe that there is a high probability for gaining an outcome that they sufficiently value. Higher performance could be obtained under difficult budgets and situations of higher expected reward (which is also associated with increased satisfaction amongst employee). High remuneration can occur if excessive allocation and size of company remuneration charge. If this happens, the risk on management budget will halt because of the volatility expenditure occurred in the department. Trotman et al. (2011) suggests that social concerns might reduce the need for extensive incentive contract.

The second gradient shows the remuneration level is high, but SR is in low level indications of agency cost or earnings management activities. Higher remuneration which is considered 'unfair' to every layer of management and the executive members will cause the emergence of agency cost. The cost is loosely enforced by the highest governance body without the control from the body. Coletti, Sedatole and Towry (2005) find the control systems need to be strong enough to maintain the cooperation between collaborators. The control on practices is intense through disclosing on specific reporting.

The third gradient indicates that RL is low even the lower magnitude of SR occurs because of the erroneous basic measurement and improper allocation. Consequently, the purpose of the EA is not achieved. At last, the fourth gradient points out that the RL is conversely low with the high SR. In the long term the goal will be reached. But it is not possible to happen because there is no compensation for management in engaging the long term practices. Kuang and Moser (2009) find that employees will either reject or accept the contracts, then reduce the effort because there is no reciprocity.

\section{Recommendation}

Further research on this concept needs to continue studying behavior management report sustainability of the environment. This can be associated with a supported motivation of remuneration. It can be measured by 
Tobin's $Q$ to examine remuneration level associated with performances (financial and comprehensive disclosures on EA). Furthermore, this behavior could constitute the base of earnings management behavior. Thus conservatism principle is required to determine the amount of costs, and to take into account the sustainability of the activities that provide long-term positive impact for the company.

\section{References}

Association of Chartered Certified Accountants., 2004. Advances in Environmental Accounting: 65

Barbier, E. B. 1989., The Contribution of Environmental and Resource Economics to an Economics of Sustainable Development. Development and Change 20(3), 429-459

Bassett, M, Ping-Sheng Koh, and I. Tutticci., 2007. The Association Between Employee Stock Option Disclosures And Corporate Governance: Evidence from An Enhanced Disclosure Regime. The British Accounting Review 39(4), 303-322.

Beck, A. C, D. Campbell, and P. J. Shrives., 2010. Content Analysis in Environmental Reporting Research: Enrichment and Rehearsal of The Method in A British - German Context. The British Accounting Review 42(3), 207-222.

Benoit-moreau, F and B. Parguel. 2011., Building Brand Equity with Environmental Communication: An Empirical Investigation in France. EuroMed Journal of Business 6(1), 100-116.

Bewley, K., 2005. The Impact of Financial Reporting Regulation on the Market Valuation of Reported Environmental Liabilities: Preliminary Evidence from US and Canadian Public Companies. Journal of International Financial Management and Accounting 16(1), 1-48.

Brown, J. and M. Fraser., 2006., Approaches and Perspectives in Social And Environmental Accounting: An Overview of The Conceptual Landscape. Business Strategy and the Environment 1(15), 103-117.

Cagatay, S and H. Mihci. 2006., Degree of Environmental Stringency and The Impact on Trade Patterns. Journal of Economic Studies 33(1), 30-51.

Cho, C. H. 2007. Legitimation Strategies Used in Response to Environmental Disaster: a French Case Study of Total S.A.'s. Quebec, Canada.

Coles, J., N. D. Daniel., and L. Naveen., 2008. Boards: Does One Size Fit All?. Journal of Financial Economics $87(2), 329-56$.

Coletti, A. L., K. L. Sedatole, and K. L.Towry., 2005. The Effect of Control Systems on Teams and Alliances: Trust and Cooperation in Collaborative Environments. The Accounting Review 80(2), 477-500.

Darmadi, S. 2012., Remuneration of Board Members in a Two-Tier System : The Indonesian Evidence, in Green Concern: Peran Akuntan dalam Mewujudkan Bisnis yang Sustainable, 21-22.

Eugénio, T. C. P., 2009. Social and Environmental Accounting: A Case Study on A Portuguese Cement Company. Disertation April, 1-262.

Farouk, S., J. Cherian, and J. Jacob., 2012. Green Accounting And Management For Sustainable Manufacturing In Developing Countries. International Journal of Business and Management 7(20), 36-44.

Firoz, CH. M., and A. Ansari. 2010., Environmental Accounting and Intemational Financial Reporting Standards (IFRS). International Journal of Business and Management, 5(10), 105-112.

Freedman, M. and A. J. Stagliano., 2004. Environmental reporting and the resurrection of social accounting. In Re-Inventing Realities Advances in Public Interest Accounting 10, 131-144. Elsevier Ltd.

Global Reporting Initiative., 2011. G4 Sustainability Reporting Guidelines. Amsterdam, NL: GRI.

Guo, Z., Ning Ai, and K. R. Polenske., 2008. Evaluating environmental and economic benefits of yellow dust storm-related policies in north China. International Journal of Sustainable Development and World Ecology 15(5), 457-470

Hunton, J. E and J. M. Rose., 2008. Can Directors' Self-Interests Influence Accounting Choices?. Accounting, Organizations and Society 33, 783-800.

Husser, J., Jean-Marce André, and G. Barbat., 2012. CSR and Sustainable Development: Are The Concepts Compatible?. Management of Environmental Quality: An International Journal 23(6), 658-672.

Jones, Michael J. 2003. "Accounting for Biodiversity: Operationalising Environmental Accounting". Accounting, Auditing \& Accountability Journal 16(5): 762-789.

Kuang, Xi, J., and D. V. Moser. 2009. Reciprocity and the Effectiveness Of Optimal Agency Contracts. Accounting Review 84(5),1671-1694.

Libby, R. and M. G. Lipe.. 1992. Incentives, Effort, and The Cognitive Processes Involved In Accounting-Related Judgments. Journal of Accounting Research 30(2), 249-273.

Li-Chin, J. H., and M.. E. Taylor., 2007. An Empirical Analysis of Triple Bottom-Line Reporting and Its Determinants: Evidence from the United States and Japan. Journal of International Financial Management \& Accounting 18, 123-50.

Pickett-Baker, J. and R. Ozaki. 2008., Pro-environmental Products: Marketing Influence on Consumer Purchase Decision. Journal of Consumer Marketing 25(5), 281-293.

Raska, D. and D. Shaw., 2012. When Is Going Green Good for Company Image?. Management Research Review 35, 326-347. 
Tilling, M. V., 2008. Refinements to Legitimacy Theory in Social and Environmental Accounting Not One Theory but Two (at Least). Commerce Research Paper Series No. 04-6, 1-11

Trotman, Ken T., H. C. Tan, and N. Ang., 2011. Fifty-year Overview of Judgment and Decision-Making Research In Accounting. Accounting \& Finance 51(1), 278-360.

Yakhou, M. and V. P. Dorweiler., 2004. Environmental accounting: an essential component of business strategy. Business Strategy and the Environment 13(2), 65-77.

Yang, Fang., Burak Dolar, and Lun Mo. 2014. CEO Compensation and Firm Performance: Did the 2007-2008 Financial Crisis Matter?. Journal of Accounting and Finance 14(1), 137-146

Yusoff, H. and G. Lehman., 2009. Corporate environmental reporting through the lens of semiotics. Asian Review of Accounting 17(3), 226-246. 